\title{
The China Dream - The Search, Evaluation and Analysis of Existing Problems
}

\author{
Lei-xin $\mathrm{Su}^{1}$, Jian $\mathrm{Wu}^{2}$, Yi Liü,* \\ ${ }^{1}$ International College, Northwest A\&F University, China \\ ${ }^{2}$ College of Media and International Culture, Zhejiang University, China \\ ${ }^{3}$ College of Humanities and Social Development, Northwest A\&F University, China
}

Copyright $\subset 2017$ by authors, all rights reserved. Authors agree that this article remains permanently open access under the terms of the Creative Commons Attribution License 4.0 International License

\begin{abstract}
With the culture concept, the China Dream is getting to permeate through every field of our lives. However the current situation is not that good in China, people still disseminate and introduce the traditional culture in an original way. Through the text analysis, questionnaire and comprehensive observation, there are several problems in China dream, in addition, there are different bottlenecks with the China Dream when facing the spread internally and externally, we find out that the Chinese government has set up an empty target for the wrong purpose from the very beginning, turning Chinese dream into the means of improving soft strength, not focus on our excellent tradition culture, to give a core connotation to China dream. This research is completely different with Chinese scholars, who focus on the establishment of the theory, or try to give a reasonable explanation for the Chinese government's stand. I believe the existing problems of China dream is caused by the Chinese government's position at the beginning of the decision. Now it's just payback time. So it's even more important to think about where the Chinese traditional culture should go next.
\end{abstract}

Keywords The China Dream, Soft Power, Spread, Existing Problems, Chinese Government

\section{Background/ Objectives and Goals}

The China Dream is achieving the Chinese nation's bright prospects, which is the greatest dream of Chinese nation since early modern times. In China, the spread of the dream is closely linked to the development of the soft power. Recently during the CPC politburo's 12th collective learning, President $\mathrm{Xi}$ pointed out that improving the soft power of China is of great significance to achieving the Chinese nation's bright prospects and the "two hundred-year" plans. The incisive statement around attempting to temper the foundation of the soft power, to spread Chinese traditional culture, to show the unique charm and to get more voice in the world are four basic parts outlined by President Xi as the fundamental guideline to building a socialist country of great civilization and improving her soft power.

According to Joseph Nye, the former Dean of Kennedy School of Government, Harvard University (1990), He described the concept of "Soft Power" as the ability to get impacted by parts of its culture. Reporting this new concept shows that the Communist Party of China have regarded improving the soft power of China as the new Strategic focus of achieving the Chinese nation's bright prospects and also regarded soft power of culture as the spirit motivation. Intelligence support ideological guarantee of the development of modern society, which becomes more and more important to increase the national cohesion, creativity and comprehensive national strength.

Comparing the China Dream with the America Dream, the first main difference is the cultural tradition and psychology while the other is the political theory and structure. In addition, China Dream has more problems to face when compared with the matured and well-accepted America Dream system.

Nowadays, Chinese scholars have made many achievements in the soft power. Hong Hua said in Assessment and Report of China Soft Power that improving the soft power is an important method to get rid of the Paradox of the rise of the great powers, a significant guide to the peace way that China chose, a mark that China has risen up. Furthermore, Luo Neng sheng and Xie Li researched on the Assessment and Report of China Soft Power and Building model. They designed a relatively complete index assessment system which uses Analytic Hierarchic Process (AHP) to ensure the weight of each index. This later helps in building multilevel assessment model that gives research foundation to scientific and quantitative assessments to the soft power of the country as well as compare with other country of the world. Also, Zhong Xin and Huang Chao in their research "Three methods of assessing the soft power and their principle" described the soft power assessment model in the world. This includes: impression type 
assessment model, source type assessment model and data base assessment model which provides a new thinking direction to complete the assessment model.

\section{Methods}

Through the comparison between China and the west, find the blind spot in the "Chinese dream" which the Chinese government always talking about. In order to make the data objective, the article uses a lot of data from the Chinese government reports. Such as the people's daily, the Communist Party of Chinese control etc. The questionnaire survey was also adopted to support my opinion about China dream. We chose the students in a 985\&211 (a total of 139 top university in China) renowned universities in China. We found a higher level of enthusiasm for the questionnaire and stronger background knowledge in our respondents that of the average university student. Depending on the credibility, usefulness and clarity of answers we obtain, we will work to further optimize and improve our assessment form and ensure that it has a higher level of scientific utility.

\section{Results}

The final realization of "China Dream" depends on the gradual improvement of soft power. Although according to Pew and many other investigation institutions, soft power can be exhibited in many different dimensions. But in China, the reason why the government attaches great importance to the Chinese dream, because they believe that if the Chinese dream can be popular in China and the world, it will be the best proof of the promotion of soft power. I think that's very shortsighted. That's why even the Government, scholars, research institutes and functionaries discovered the focal point of soft power by engaging in an extensive research. Also a more specialized research Centre for soft power has since been established, yet the country's soft power is still considered weak and the recommendations of Chinese culture are still in a very primitive state.

Before putting forward the Chinese dream, China scholars discoveries that U.S and Japan among other countries don't directly make use soft power as the core of strategy. But they have diplomatically clear Culture strategy which can be illustrated by the effect of animations and Hollywood. This Cultural strategy illustrates their thinking and consciousness, the mind of democratic freedom and value orientation. Not only huge commercial profit has been made from these cultural productions, enormous political influence and social effect has also been created at the same time. They believe there are two main aims of their cultural strategy: First is for economic interest while the second to achieve acknowledgment of values from other countries of the world.

In China, because of the government wrong starting point, the foreign 'Chinese Imagination' is still disordered with lots of in directionality and misunderstandings owing to the fact that the resource of Chinese traditional culture has not been fully transferred to actual productivity. Quantities of art fields including performances, language culture and publication of books are encountering 'Culture Deficit'. When compared with the 'Over-exported' of foreign trade, the foreign cultural and dissemination is now 'Over imported'. This can be depicted in Fig. 1:

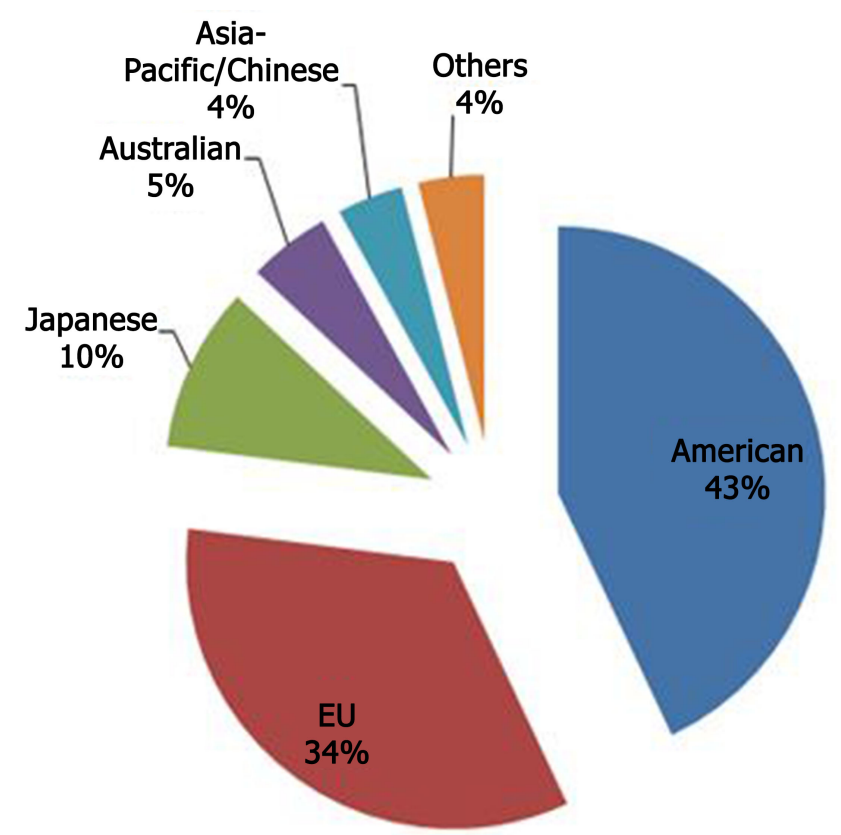

Figure 1. Proportion parts of country cultural industry in the world cultural markets in 2014

As the Chinese dream as a means to enhance soft power, rather than focus on its own content, the Chinese dream even is puzzling in China. That cause of stagnancy in the research of the soft power can traced to scholars solely focusing on theoretical and definitional construction. They focus on impracticalities like the model- building and determination. Owing to this, it's actually difficult to get a decisive direction for the realization of the "China dream".

I believe the spreading of the China Dream should be a dynamic process; therefore, it has something to do with not only the increase of soft power but also the methods and content of the China dream. And at present the spread of the China Dream are associated with a lot of difficulties inherent in China and other countries of the world. I put forward the five difficulties, the purpose of this study is twofold: 1) To clear what are the problems of the Chinese dream caused by the mistakes of the Chinese government; 2) Trying to figure out how to solve these problems and find a new way for Chinese tradition culture.

\section{Discussion and Conclusion}

\subsection{The Connotation of the China Dream is a Controversial Issue Focusing on the Theories of "Dualism" and "Trialism"}

In China the connotation of the China Dream is still not 
sure, as what I said, the China scholars only want to prove China dream is so good and it's means China's soft power is very powerful. It shows they forget to study the China culture itself.

'Dualism': The Chinese word "Country" consists of "the nation" and "the family" having the same destiny. The China Dream is the combination of the country's dream and the family's dream consisting of two complementary parts. On one side, it is a shared dream and on the other side, a realistic spirit of hard work.

'Trialism': A dream of a great country is not a one-dimensional dream from the perspective of individuality, it is a dream originated from the collective effort of individuals. Therefore, the dream to make China a great nation originated from the perspective of the Chinese nation. The China Dream is not only aimed at achieving prosperity for China, national rejuvenation and happiness for her people but also targeted towards achieving modernization, socialism and national revival. This would enable the nation to contribute more to other nations of the world. Therefore, making people richer is the foundation, making our country stronger is the key and realizing the great rejuvenation of China is the final goal. These three items are indispensable and it's only when they are achieved that the China Dream can be realized.

These two theories are practically the same but originated from different origin. The former start from the personage and the latter is from the angle of the whole nation.

The argument about the uncertainty of the China Dream is considered baseless because even though the study is the same, the people encountered, the content that will be advocated, the spreading method employed and the purpose that will be realized will all be different. The former theory is for China which eventually becomes the traditional culture, aiming at increasing the Chinese cultural quality, cohesion and pride. The other theory is for the foreign countries. This is a dream aimed at revitalizing the Chinese nation, making her stronger, making the people happier and ensuring greater contribution from China to the rest of the World. Knowing that the China Dream is aimed at two different situations, the cultural core it advocates is supposed to be treated differently.

In China a teacher like me in University is very concerned about this, but unfortunately, there is no clear explanation from institutions or authorities. I think on one side, it is because the concept of the China Dream is too huge to explain, while on the other hand, it shows that the Chinese government does not care whether the Chinese dream has the core connotation, like American dream does--'the dream comes true'. Their concern is not the people but the impact.

\subsection{There are Difficulties in Spreading the China Dream at Home and Abroad}

Internally, the main challenge is that the mainstream values are not really clear. The China Dream forwarded by President $\mathrm{Xi}$, to a certain extent, focuses on the traditional culture value. In a research to get an understanding of culture value, as reference, in 2014--2015 we use Questionnaire survey methods did research in Chinese university which is in project 985 and project 211 (a total of 116), the survey of contemporary Chinese students (Who has taken Chinese traditional culture course) attitude about Chinese traditional culture, the research including a total of 5500 questionnaires, 5483 valid questionnaires, Overall valid questionnaires reached $99.72 \%$. The results (Fig.2 and Fig.3) shows that over half of the students are aware of the traditional culture, but without a specific connotation and hence pessimistic about inheriting the culture.

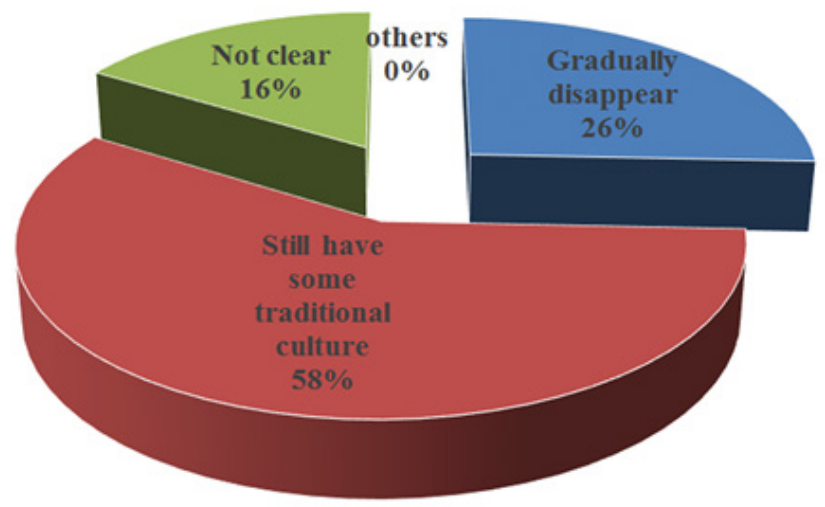

Figure 2. Do you think Chinese still have our traditional culture or traditional life?

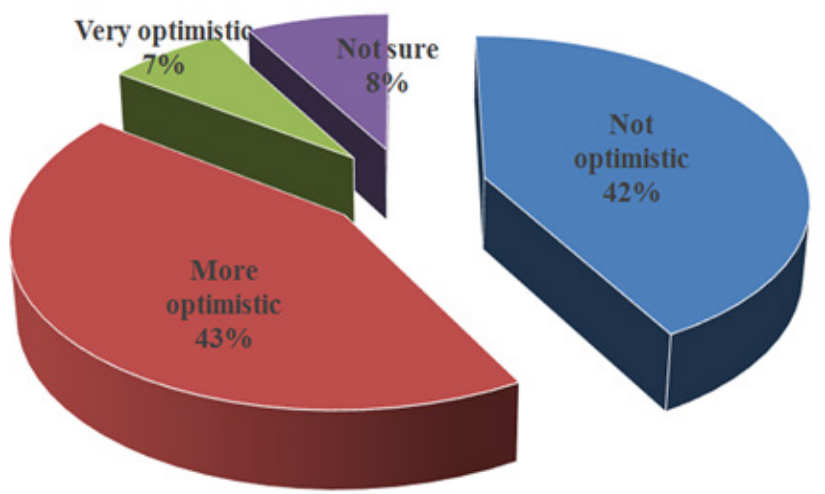

Figure 3. What do you think about the future of Chinese traditional culture?

Why we get such a result in a group of young Chinese Elite? I find out that there are some typical slogans like "walk the China road, promote the China spirit, gather the China power and realize the China Dream" which makes people get to know the propaganda of the China Dream. Even though these slogans are more profound, yet questions like the definition of the nation's contemporary mainstream core value and which part of the traditional culture should be inherited has not been answered. This is exactly caused by what we are talking about the Chinese government does not care about the connotation of the Chinese dream. Therefore it would be very difficult to combine it with the national interest and people's livelihood. 
Culture has many attributes. Some cultural elements can develop to be cultural products which in turns become cultural industries like Hollywood and Cartoon as earlier mentioned. The Western countries' cultural industry has been the pillar industries in their national economy and has created lots of wealth. Now China cultural industry is in a start-up stage. The cultural development is still very low and therefore necessary to strengthen the Chinese quality by improving the culture.

\subsection{The Difficulty is Particularly Obvious in the Area of Chinese Culture Transmission}

According to the Chinese media in 2015, between two countries, there are serious deficit in the language culture. There are currently about 24,000 high school students in America studying Chinese, while the number of students studying French is more than 100 million. Also, there are over 3,000 Universities in the US with only about 800 of them running Chinese language course. The establishment of the Confucius Institute has played an important role in alleviating these problems. However, the new problem emanating is that there is no clear cultural output target because even Chinese also don't what is the China dream. Emphases has been on improving the soft power in order to promote China's image and the nation has been trying to achieve "the dream of the world" but there is no clear cut about the kind of image that should be established, this is considered a great loss.

In addition, in the process of improving the soft power, foreigners may not recognize or appreciate the effort that has been applied. Recently, the news that Sweden will close the European earliest Confucius institute fully illustrates this point. According to "the voice of the German" report on January 112015 the reason why the University of Stockholm, Sweden still operates the Confucius institute is just because the institute is currently supported by the Chinese government. The Chinese government provides funds, teachers and teaching materials. Therefore, they thought that Confucius institute is a branch of the Chinese government which is however contrary to academic freedom.

I don't think the problem of Chinese government is to find a balance between cultural communication and academic freedom. In fact I think the misunderstanding is coming from China government itself could not find the core value of the so-called China dream view, such as the Hollywood cultural in USA, this value should be a part of the cultural industry, not in turn, pay a lot money and try to expand the influence of China.

\subsection{Several Misunderstandings Usually Arise When China Tries to Show up during Political and Diplomatic Occasions}

For example during the 2014 OPEC meeting, all the national leaders wore "tang suit". The first lady of China also wore the suit during the occasion. As a result of this, foreign leaders and people at the occasion thought that "tang suit" is Chinese national dress. But it can be noted that the "tang suit" is different from the traditional Chinese dress. It came from the Qing" long gowns mandarin jackets deformation but has been influenced by modern elements. Therefore it will be difficult to say that the suit represents the essence of Chinese traditional clothes.

Tang suit and Hanfu, which should represent of China? This is a very important principled matter to Chinese, because we can't forget the traditional and history in China. According to the information available online (Yahoo Knowledge in Japan 2012) our body, skin and hair are heritage from ancient china which should not be damaged, but the question is why all the men chose to shave their hair in Qing dynasty. The answer is that "Chinese finds it very easy to forget and betray their ancestors". After the government from Manchu, they forgot the meaning of resistance. Generally, the Japanese called all the former Chinese dynasties "China", while they named the latter Qing dynasty "ridiculous". However, we regard the "Hanfu" as a part of national consciousness. "Making driving machine imitates the Yin Dynasty while wearing clothes imitates the Zhou Dynasty", this is a key principle Confucian students keep when governing country As a result of the deep impact of Confucian thought, many countries like Japan, Mongolia, the Kingdom of Bhutan and Korea have some characteristics of "Hanfu" in their traditional clothes. Therefore the "tang suit" is not the traditional suit of Han race so if it's used at any point, it's the cultural symbol.

This shocking fact shows that the Chinese government even doesn't care or respect the traditional Chinese cultural, so in China from the top down, talking about China dream we can only find the big but empty name but not the true values of Chinese cultural.

\subsection{Foreigner's Imaginations about China also Constitute a Major Problem}

Yearly, Chinese consumes large number of luxury goods. In 2015, Chinese buys 107 billion of luxury goods which covers a quarter of the world's luxury market. As a result of this, Chinese consumption is gradually rising and these luxury goods are been combined with so-called Chinese elements. However, these so called elements are not sufficient enough to explain the meaning of the Chinese traditional culture therefore leading to misinterpretation. I can't blame foreigners because we also not sure what it is. But this imaginations is too far and old form contemporary China.

In early 2014, there are many imaginations from the Holly-wood workers on contemporary China especially as regards the movie titled "Return of the Dead". However, those imaginations still belong to the 70's in the last century. I often play the Chinese scene of this American TV series, let the students guess it is what age in China, and they always answer the same "it's the 70's in the last century". In the USA reality show "The face" (2013), the contestants were 
required to create a work of art based on the Chinese culture. However, nobody was able to differentiate the Chinese culture and the Japanese culture when a player shops at the Japanese shop by mistake. Whatever the players or the judges were building or evaluating are so-called "Chinese elements". The similar examples are everywhere!

The cultural strategy should be clearly and properly guided but China in her part has not been able to take this seriously. I believe this is because the Chinese government made a mistake from the beginning, so now it's payback time.

\section{Summary}

The China Dream is a national dream, an Asian dream, and also called the world dream because it explains the essence of the combination of the traditional culture with the modern culture. Therefore, it should have a specific cultural orientation. But up to date, scholars in their research are still at the surface level. Some people think that we should carry forward some traditional values like respecting the old and cherishing the young to realize national prosperity, national revival and ensuring happy life for the people while some people think that we should set the environment to be in support, thereby placing more value on ecological civilization construction to ensure the development of our nation, and also contribute more to the rest of the world.

These different opinions are lacking new idea and practical significance because the Chinese government has set up an empty target for the wrong purpose from the very beginning. Turning Chinese dream into the means of improving soft strength, not focus on our excellent culture tradition. I believe it's wrong and it may be cost us more money and energy to change the world's view on China. What we can do now is to calm down, reconsider the core of Chinese traditional culture, to give the Chinese dream a vibrant and confident core, and to reshape the image of china in the world.

\section{Acknowledgement}

This research was financially supported by the Course construction of public art education in agricultural and Forestry Universities (JY1504074).

\section{REFERENCES}

[1] Cheng, M. D. \& Zhang, X. C. (2013). "China Dream" Review. Socialism with Chinese Characteristics, (2), pp58-65.

[2] Gulnara, K. (2009). Application of Soft Power Strategy on Asian Civilization Spaces. Contemporary International Relations, (6), 13-27.
[3] Guo, Y. Z. Li, X. M., \& Wang, Q. L. (2014). Cultural Soft Power-based Brand Culture. Marketing Strategies of Tourist Destinations. Journal of Landscape Research, (Z1), 51-52.

[4] Jin, W. \& Ai, H. (2013). Vision and Actions of People-to-People Diplomacy within to the Blueprint of the "Chinese Dream"--The Case of the CYMCA and CYWCA. International Understanding, (2), 46-49.

[5] Li, D. X. \& Ma, J. T. (2015). Cultural Soft Power and China's Improvement. International Understanding, (3), 16-19.

[6] Li, J. R.(2013). The China Dream: A Dream of Human Rights for the Chinese People. Human Rights, (6), 2-4.

[7] Li, J. R.(2011). Interpretation of Chinese dream and design Chinese road .China Economic Times, 17(6), 1-2.

[8] Lin, P. X. \& Liu, G. M. (2013). Strive for Realizing the "Chinese Dream"_-Achieve National Rejuvenation. Peace, (1), 28-30.

[9] Luo, H. C. (2014). Boost the Modernization of Human Rights Protection Systems and Endeavor to Fulfill the Chinese Dream. Human Rights, (6), 4-7.

[10] Luo, N.S. \& X, L. (2011). National cultural soft power evaluation index system and Model. Pursuit, (9), 22-24.

[11] Men, H. H. (2007). China's soft power Assessment Report. International Observer. (3), 37-46.

[12] Meng, D. F. \& Wang, Z. B. (2013). The content, structure and route optimization of China dream. Chongqing Social Sciences, (5), 12-23.

[13] Myrdal, G. (1944). An American Dilemma: The Negro Problem and Modern Democracy. New York: Harper and Brothers.

[14] Si, Q. R. (2014). The Coordinated Development of Sports Industry and Tourism under the Perspective of Soft Power: A Case Study of Henan Province. Asian Agricultural Research, (2), 39-43.

[15] Zhao, T. Y. (2014). The "China Dream" in questions. Economic and Political Studies, (1), 127-142.

[16] Wang, B. (2015) CAFIU Holds a Seminar on China-Japan Cultural Exchanges and Soft Power. International Understanding, (3), 39-40.

[17] Wang, D. (2013). A Brief Stylistic Analysis of "Chinese Dreams and American Dreams" delivered by Bai Yansong. Overseas English, (3), 285-286.

[18] Wang, X. G. (2015). The Chinese Dream and Human Rights in Contemporary China: A Legal-political Perspective. Human Rights, (2), 122-132.

[19] WILliaM, A. C. (2014). The China Dream and American Dream. Economic and Political Studies, (1), 143-160.

[20] Zhang, B. (2013). The Chinese Dream-A New Dream Provided By China For The World. Overseas English, (18), 228-229.

[21] Zhao, Z. X. \& Liu, G. (2015). The "One Belt and One Road": the Bridge between the Chinese Dream and the World Dream. Peace, (1), 6-9. 